\title{
Design and Development of A First- and Second- Generation Balanced Scorecard in a Company in the South of Guanajuato
}

\author{
Sandra Vianey Mata and Roberto Baeza Serrato
}

\section{ABSTRACT}

\begin{abstract}
The purpose of this article is the development of a first and second generation in a manufacturing company in southern Guanajuato. For the development of the first generation BSC, a strategy was identified based on the company's vision, which consists of making deliveries in the shortest time possible. Strategic objectives were determined in each of the four perspectives: financial, customers, internal processes, and learning and growth. The perspective is highlighted: Financial and Internal Processes, with the strategic objectives: "Reduce the number of returns so as not to reduce the utility of the company" and "Reduce the percentage of failures un the design of the boxes to deliver quality products to the customers". The goals and indicators were established, as well as at least four initiatives that will help us in the fulfillment of each of the objectives. Subsequently, 3 strategic objectives are identified for each of the perspectives, these objectives are connected through a cause-effect relationship. The main one being: "Increase the speed of delivery of orders to generate reliability in customers". Once the objectives have been identified, the series of activities to be carried out to meet these goals are described, and with this the second generation BSC is developed. Finally, a management tool is obtained that allow the company to comply with the proposed strategy.
\end{abstract}

Keywords: Balanced Scorecard, Customers, Financial, Internal Processes, Manufacturing Industry, Strategy.

\section{INTRODUCCIÓN}

According to Forbes 2019, the manufacturing industry, is dedicated exclusively to the transformation of different raw materials into finished products and goods ready to be consumed or, to be distributed by those who will bring them closer to final consumers. In Mexico there are many manufacturing sectors that are a fundamental part of the economy. According to INEGI, in 2019 the manufacturing industry had a great performance, with a growth rate of $10.5 \%$ compared to the same previous period, and generated $\$ 225$, 616 million dollars only in exports. The State of Guanajuato ranks third at the national level in the value of accumulated production of the manufacturing industry. The Bajio area contributed $13.6 \%$ of the employed personnel that worked in the country's manufacturing industry, which represented its greatest contribution. The growing importance of small and medium-sized enterprises (SMEs), especially in developing countries, is recognized for the contribution to employment and economic well-being [1]. The SME represents more than $95 \%$ of the total of existing companies; covering $87 \%$ in the services and commerce sectors; and generates $64.26 \%$ of employment in the region [2]. The SME is basic for industrial production. It faces increasingly high demands and new opportunities that merit an evaluation and development of its processes [3]. In Guanajuato, SMEs generate 50\% of the
Gross Domestic Product and up to $70 \%$ of the total employment of the entity [4]. One of the disadvantages that SMEs face is the form of management, because they do not have the knowledge about the usefulness of different business management tools that allow them to increase their efficiency and economic profitability. A tool that allows managing the strategy is the Balanced Scorecard, whose fundamental objective is to convert the strategy of a company into action and result through four perspectives: financial, Customers, Internal Processes and Learning and Growth [5].

The vision of the company requires the inclusion of several perspectives, financial indicators are not enough to analyze the state of an organization, they only present results from the past and that sometimes can be generated at the expense of quality and customer satisfaction, Balanced Scorecard monitors not only financial indicators, but also indicators related to the client, internal processes and learning and growth processes, which in the end are the ones that will lead to the future financial results of the company [6]. The Balanced Scorecard is a revolutionary tool to mobilize people towards the full fulfillment of the mission, through channeling the energies, skills, and specific knowledge of the people in the organization towards the achievement of long term strategic goals [7]. The Balanced Scorecard is a strategic management tool that allows you to have under control and related all those measures that represent the key variables to run a business [8]. In addition, it makes it possible to translate 
the organizational strategy, through a coherent set of action indicators, which, together with other management tools, distinguishes intangible assets as a new main actor in the Information Age [9].

Due to the importance that SMEs have in the economy, and how significant it represents for them to have a management tool that allows them to increase their efficiency and economic profitability, a proposal was made to implement a first and second generation Balanced Scorecard in a SME in the South of Guanajuato that works in manufacturing sector, with the aim of generating a strategy that allows it to achieve the vision they have outlined and the tools that it to carry them out permanently so that they generated a competitive advantage within the market. The development of the work consists of 14 parts, in which the state of the art is highlighted, since an exhaustive review of the literature was carried out, in which the research works of different researchers were carefully selected, allowing to identify the applications that have been carried out in the manufacturing sector of the Balanced Scorecard

\section{STATE OF THE ART}

This section presents the results of an exhaustive research search with Balanced Scorecard applications in the manufacturing industry.

In [10] elaborate a Balanced Scorecard proposal that serves as a guide for small and medium-sized entrepreneurs carried out analysis of key documents of the company and applied questionnaires defining as a strategy: "Increase in the perception of the beneficiaries of comprehensive health satisfaction". Finally, the BSC allowed them to establish the relationship between the indicators and the strategic objectives to reach the fulfillment of the hospital's mission.

In [11] present a proposal for the application of the Balanced Scorecard in a manufacturing industry. They present it in two stages, the first takes the four perspectives and relates them to negative aspects, while in the second part, transforms them into positive aspects to consolidate and strengthen the sector. It is based on the strategy: "Formulate decisions so that manufacturing contributes to the achievement of competitive advantages in the long term".

According to [12] analyzes the application of the Balanced Scorecard in the library field from its four perspectives. Establishing as a strategy: "Increase Feedback". They enhance the financial outlook. They facilitate the achievement of long-term strategic objectives and indicators for each perspective.

In [13] propose a Balanced Scorecard from the client's perspective to a company in the textile sector in the southern region of the state of Guanajuato, defining as the strategy: "Provide machinery for functional knitting, at a good price and with quality above the competition". The company already had a Balanced Scorecard that allows them to improve the utility of the company, however, with the entry of Chinese products they found it necessary to implement a Balanced Scorecard focused on the customer's perspective. Finally, they form their own model of the BSC, having as strategic objectives of this perspective Market share, Customers growth, Customer retention and Customer Satisfaction. This proposal allowed them to identify what the real needs of the clients are.

In [14] implement the BSC to improve the internal control of a company. They detect as a relevant weakness the lack of knowledge of the staff about the indicators and meters for the fulfillment of the company's objective. They define as strategy: Determine the perception of customers with respect to the products and services offered by the company". Based on these results they develop the strategic map for each perspective of the Balanced Scorecard.

In [15] determines the contributions of the BSC methods to identify the relationship between the objectives and the activities to examine how the Balanced Scorecard should be formed in a manufacturing company. Determines as strategy: "Increase the income of the company". As a result, it creates awareness among the production, marketing, human resources, and finance departments and increases coordination within the organization.

In [16] Realize a case study in a leading beverage manufacturing industry. They identify key performance indicators, and the industry value chain tells them to focus. Analyze the critical factors and use the BSC to measure KPI's and objectives. The development of the BSC helped the company to identify that the perspective that most critical factors were detected was that of internal processes.

[17] examined the use of the BSC in small manufacturing companies. He used a qualitative research approach to collect data on two groups of participants: "Those who used the BSC" and "Who never used it and do not plan to use it in the future". The main finding of the study demonstrated thar the BSC as a performance measurement system can be used by small manufacturing companies, contradicting the argument of some scholars including Kaplan and Norton that the BSC was originally designed for large scale companies.

The research works are fundamental piece in the development of the first- and second-generation Balanced Scorecard proposed in this article, due to the methodology supported by each of these, in addition to the fact that each of this tool are based on the mission and the vision of the company. Once the research of the different authors has been analyzed, it can be concluded that the contribution of this research work consists of the design and development of the first two generations of the Balanced Scorecard, in addition to focusing on a strategy that allows the reduction of delivery times within the company, which will allow it to have a competitive advantage within the market and as a consequence increase the company's profits, as can be seen, most authors focus first on reducing the costs of the company, identify the critical factors, and in other cases the steps to follow for the implementation of Balanced Scorecard within the company.

\section{METhODOLOGY}

This section presents the methodology used for this research work, which is organized in 14 stages: Review of the literature, Identification of the case study, Review of the state of the art, Know the explicit statement of the company, Analyze the company, Define the strategic objectives, Establish the measures, Determine the goals, Build the initiatives, Design Second Generation, Results and Conclusions. Regarding the review of the theoretical 
framework, a review of the most important concepts of the Balanced Scorecard was made, which supports this work. The strategy and the strategic objectives were defined. An important part in the development of this work was the state of the art, since an exhaustive review of the different investigations was carried out in scientific articles that have used this methodology in the manufacturing industry, strengthening the research work.

The case study was identified, that is, we worked together with a manufacturing company from the south of Guanajuato, which provided the necessary information for the development of the different Balanced Scorecards. Once the case study was identified, the mission, vision and values of the company were identified, on order to determine the strategy. The strategic objectives of each of the perspectives, financial, clientes, internal processes and process and learning were defined. The measures that will serve to, after determining, in addition to identifying the initiatives that will help us to achieve each of the strategic objectives. Once all the necessary information was obtained, the first generation BSC was designed. For the development of the second generation $\mathrm{BSC}$, the main causal relationships between the strategic objectives were visually documented, once the second generation BSC was designed. An important part in the development of this work was the state of the art, since an exhaustive review of the different investigations was carried out in scientific articles that have used this methodology in the manufacturing industry, strengthening the research work.

\section{Comprehensice review of BSC applications}

\section{Select SME}

3. Identify the company's strategy

4. Design First Generation BSC

5. Identify the main causal relationships

\section{Design seconf generation BSC}

\section{Write the results obtained}

Fig. 1. Methodology.

\section{RESULTS}

As mentioned in the methodology, the first step for the development of the Balanced Scorecard consisted ok knowing the mission and vision of the company, since they are a fundamental key in the development of the Balanced Scorecard.

Mission: At Cartoempaques we protect and take care of our clients' products during their transport and storage with the design and creation of high-quality corrugated cardboard packing and flexibility in delivery times and volumes.

Vision: To be leading company at the national level in the generation of cardboard solutions with high-tech equipment, with trained personnel who are committed everyday to quality and service to our customers.

Strategy: Make deliveries to our customers in the shortest possible time to remain positioned as the company that places orders almost immediately.

\section{$>$ Balanced Scorecard First Generation}

Once the company's strategy had been identified, the strategic objectives were raised regarding the financial perspective, Clients, Internal Processes and Process and learning. The measures with which the objectives will be measured were established, as well as the goals and the definition of the initiatives that will be carried out for the fulfillment of each of the objectives. From the financial perspective, the strategic objectives are focused on reducing both operating, manufacturing and logistics costs, as well as increasing sales and reducing the number of returns to increase the company's profit.

For the company it is particularly important that it comply with the strategy, since most clients prefer to place their orders with them due to the speed with which they deliver the orders, which is why the perspective of Clients and Internal Processes stand out. Regarding the customer perspective, the strategic objectives are focused on helping to fulfill the strategy, so they were designed to increase the company's delivery times, improve customer service, satisfy requirements, and innovate in the designs of the boxes to diversify customers options. Each of the initiatives were carefully deigned to meet the objectives. From the perspective of Internal Processes, the strategic objectives are specially designed to reduce waiting times and improve the quality of the products manufactured within the company. Each of the initiatives written in the different perspectives: Financial, Clientes, Internal Processes and Process and Learning will help to fulfill each of the strategic objectives.

\section{$>$ Balanced Scorecard Second Generation}

According to Kaplan and Norton, for the second generation of the Balanced Scorecard, the classification scheme of strategic objectives in the form of perspectives should help to identify the causal relationships between objectives and, ultimately, allow the effective graphic representation of the strategy.

Table II shows the Second-Generation Balanced Scorecard. For the development of the second-generation Balanced Scorecard, 3 strategic objectives were identified in each of the perspectives: Financial, Customers, Internal Processes and Growth and Learning, these objectives are connected through a cause-effect relationship, of which we can highlight: "Reduce the number of returns to achieve financial growth" in the Financial perspective, "Increase the speed of order deliveries to generate customer reliability from the Customers. Subsequently, the indicator and the consequent goal were determined, as well as the initiatives that will help in the fulfillment of each of the objectives, in continuation with the last-mentioned objective a goal of $0-1$ of failures in the designs of the boxes was established. The company registers 5 failures monthly, which causes the client to return the entire order of the batch, this failure can cause economic losses from $\$ 26,400$ to $\$ 352,000$ per batch, so it is vitally important that there is no failure in the design of the boxes. Balanced Scorecard Second Generation is a top-down management tool with building the relationships between strategic objectives and cause-effect links. 


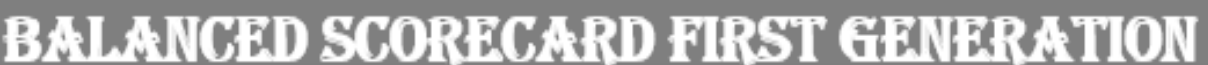

\begin{tabular}{|c|c|c|c|}
\hline \multicolumn{4}{|c|}{ FINANCIAL PERSPECTIVE } \\
\hline OBJECTIVES & MEASUREMENTS & GOALS & INITIATIVES \\
\hline \multirow{3}{*}{$\begin{array}{c}\text { Increase sales to achieve } \\
\text { financial grovth of the company. }\end{array}$} & \multirow{3}{*}{ Percentage and sales } & \multirow{3}{*}{$5 \%$} & Increase the client portfolio \\
\hline & & & $\begin{array}{l}\text { Meet customer expectation } \\
\text { Streamline the delivers of orders }\end{array}$ \\
\hline & & & Increase the productos offered \\
\hline \multirow{4}{*}{$\begin{array}{l}\text { Reduce the number of returns so } \\
\text { as not to reduce the utility of the } \\
\text { company. }\end{array}$} & \multirow{4}{*}{ Number of boxes } & \multirow{4}{*}{50} & Adequate control of orders \\
\hline & & & Increase the quality of the cardboard \\
\hline & & & $\begin{array}{c}\text { Prevent bozes from falling off } \\
\text { Staff training }\end{array}$ \\
\hline & & & Increase the quality of paint \\
\hline \multirow{4}{*}{$\begin{array}{l}\text { Reduce manufacturing costs to } \\
\text { increase the profit of the } \\
\text { company. }\end{array}$} & \multirow{4}{*}{ Money } & \multirow{4}{*}{10.000} & Optimize production processes \\
\hline & & & Train staff \\
\hline & & & Compare cost benefit of providers \\
\hline & & & Identify unnecesary activities \\
\hline \multirow{4}{*}{$\begin{array}{l}\text { Reduce operating costs to } \\
\text { increase the profit of the } \\
\text { company. }\end{array}$} & \multirow{4}{*}{ Money } & \multirow{4}{*}{10.000} & Reduce vaste \\
\hline & & & Train staff \\
\hline & & & Eliminate unnecesary activities \\
\hline & & & Preventive and Corrective \\
\hline \multirow{3}{*}{$\begin{array}{l}\text { Reduce logistics costs to } \\
\text { increase the utility of the } \\
\text { company. }\end{array}$} & \multirow{3}{*}{ Money } & \multirow{3}{*}{10.000} & Increase container storage \\
\hline & & & Avoid Excess inventory \\
\hline & & & Optimize shipping orders \\
\hline \multicolumn{4}{|c|}{ COSTUMER PERSPECTIVE } \\
\hline \multirow{4}{*}{$\begin{array}{l}\text { Produce cardboardboxes } \\
\text { according to customer } \\
\text { requirements to generate } \\
\text { customer loyalty } \\
\end{array}$} & \multirow{4}{*}{ Percentage of bozes } & \multirow{4}{*}{$5 \%$} & Have the right production team \\
\hline & & & Design the best quality cardboard \\
\hline & & & Make a good note of customer \\
\hline & & & Propose solutions to customers \\
\hline \multirow{3}{*}{$\begin{array}{l}\text { Increase the speed of deliveries } \\
\text { to the customer to generate } \\
\text { reliability in customers. }\end{array}$} & \multirow{3}{*}{ Delivery time } & \multirow{3}{*}{1 day } & Properly capture orders \\
\hline & & & $\begin{array}{l}\text { rify that gou bare the necessary ran eatet } \\
\text { Approve orders as quickly as }\end{array}$ \\
\hline & & & Place orders as requested by the \\
\hline \multirow{5}{*}{$\begin{array}{c}\text { Improve customer service to } \\
\text { generate satisfation and increase } \\
\text { customer confidence. }\end{array}$} & \multirow{5}{*}{ Satisfaction porcentage } & \multirow{5}{*}{$5 \%$} & Shov the client that it is important \\
\hline & & & Conduct satisfaction surveys \\
\hline & & & Provide customer solutions \\
\hline & & & Meet customer needs \\
\hline & & & Provide personalized customer \\
\hline \multirow{3}{*}{$\begin{array}{l}\text { Innovate in the designs of the } \\
\text { boxes so that the client has a } \\
\text { diversity of options. }\end{array}$} & & & Propose new boz designs \\
\hline & Number of designs & 2 & Involve employees in nev designs \\
\hline & & & Train staff \\
\hline & & & $\begin{array}{l}\text { Incorporate the nev designs } \\
\text { Adapt to customer needs }\end{array}$ \\
\hline Increase the number of shipments & & & Have good logistics team \\
\hline $\begin{array}{l}\text { Were the client requires them to } \\
\text { help them grov their bisiness. }\end{array}$ & Shipping percentages & $5 \%$ & Make shipments in the agreed time \\
\hline & & & Make deliveries in a timely manner \\
\hline
\end{tabular}


TABLE I: CONTD.

\begin{tabular}{|c|c|c|c|}
\hline \multicolumn{4}{|c|}{ INTERNAL PROCESSES PERSPECTIVE } \\
\hline \multirow{4}{*}{$\begin{array}{l}\text { Minimize the number of defects } \\
\text { in the production process to } \\
\text { ensure quality products. }\end{array}$} & \multirow{4}{*}{ Number of damage } & \multirow{4}{*}{10} & $\begin{array}{l}\text { Preventive and corrective } \\
\text { maintenance to machinery }\end{array}$ \\
\hline & & & Inform staff of the order required \\
\hline & & & Train staff \\
\hline & & & Guarantee quality ray material \\
\hline \multirow{3}{*}{$\begin{array}{l}\text { Reduce production time to offer } \\
\text { better delivery times. }\end{array}$} & \multirow{3}{*}{ Production time } & \multirow{3}{*}{1 hour. } & Train staff \\
\hline & & & Streanline order approval \\
\hline & & & $\begin{array}{l}\text { Design and produce orders as } \\
\text { quickly as possible }\end{array}$ \\
\hline \multirow{2}{*}{$\begin{array}{l}\text { Reduce the amount of ray } \\
\text { material ti improve the } \\
\text { productivity of the company. }\end{array}$} & \multirow{2}{*}{ Material quantity } & \multirow{2}{*}{$1000 \mathrm{mts}$. } & $\begin{array}{l}\text { Prepare an induction plan for the } \\
\text { production process staff }\end{array}$ \\
\hline & & & Design preventive and corrective \\
\hline \multirow{4}{*}{$\begin{array}{l}\text { Reduce the percentage of } \\
\text { failures in the design of the boxes } \\
\text { to deliver quality products to } \\
\text { customers. }\end{array}$} & \multirow{4}{*}{ Number of failures } & \multirow{4}{*}{5} & \begin{tabular}{|c|} 
Continuos staff training \\
Check that the paints is of adequate
\end{tabular} \\
\hline & & & $\begin{array}{c}\text { quality } \\
\text { quech }\end{array}$ \\
\hline & & & \begin{tabular}{|l|l} 
Identify that the bos is not defective \\
\end{tabular} \\
\hline & & & $\begin{array}{l}\text { Check that the printer works } \\
\text { properly }\end{array}$ \\
\hline \multicolumn{4}{|c|}{ GROWTH AND LEARNING PERSPECTIVE } \\
\hline \multirow{3}{*}{$\begin{array}{l}\text { Provide constant training of staff } \\
\text { to improve the quality of } \\
\text { products. }\end{array}$} & \multirow{3}{*}{ Staff training ratio } & \multirow{3}{*}{$70 \%$} & $\begin{array}{l}\text { Help staff to identify vith the } \\
\text { objectives of the compant }\end{array}$ \\
\hline & & & $\begin{array}{c}\text { Improve employee knovledge and } \\
\text { skills }\end{array}$ \\
\hline & & & Improve employee entry into the \\
\hline \multirow{3}{*}{$\begin{array}{l}\text { Improve the boss-subordinate } \\
\text { relationship to improve } \\
\text { communication of company } \\
\text { processes. }\end{array}$} & \multirow{3}{*}{ Staff confidence ratio } & \multirow{3}{*}{$80 \%$} & $\begin{array}{c}\text { Make the employee feel identified } \\
\text { vith the compant }\end{array}$ \\
\hline & & & Avoid employee turnover \\
\hline & & & Decrease the need for supervision \\
\hline \multirow{3}{*}{$\begin{array}{l}\text { Measure employee productivity to } \\
\text { ensure customer satisfaction. }\end{array}$} & \multirow{3}{*}{$\begin{array}{c}\text { Number of semi-annual } \\
\text { surveys }\end{array}$} & \multirow{3}{*}{2} & Conduct productivity survens \\
\hline & & & Increase training \\
\hline & & & Improve the internal processes \\
\hline \multirow{3}{*}{$\begin{array}{l}\text { Improve the vork environment of } \\
\text { the Organization for the } \\
\text { motivation and iniciative of } \\
\text { employees. }\end{array}$} & \multirow{3}{*}{$\begin{array}{l}\text { Proportion of rork } \\
\text { envoronment }\end{array}$} & \multirow{3}{*}{$70 \%$} & Motivate employees \\
\hline & & & $\begin{array}{c}\text { Make employees feel part of the } \\
\text { organization }\end{array}$ \\
\hline & & & Improve the boss employee \\
\hline \multirow{3}{*}{$\begin{array}{l}\text { Keep employees motivated to } \\
\text { avoid employee turnover. }\end{array}$} & \multirow{3}{*}{$\begin{array}{l}\text { Number of employee } \\
\text { turnover }\end{array}$} & \multirow{3}{*}{3} & \begin{tabular}{|c|}
$\begin{array}{c}\text { Motivate employees to participate in } \\
\text { company decisions }\end{array}$ \\
\end{tabular} \\
\hline & & & Recognize employees for their vork \\
\hline & & & Access to information to do their job \\
\hline
\end{tabular}


TABLE II: BSC SECOND GENERATION

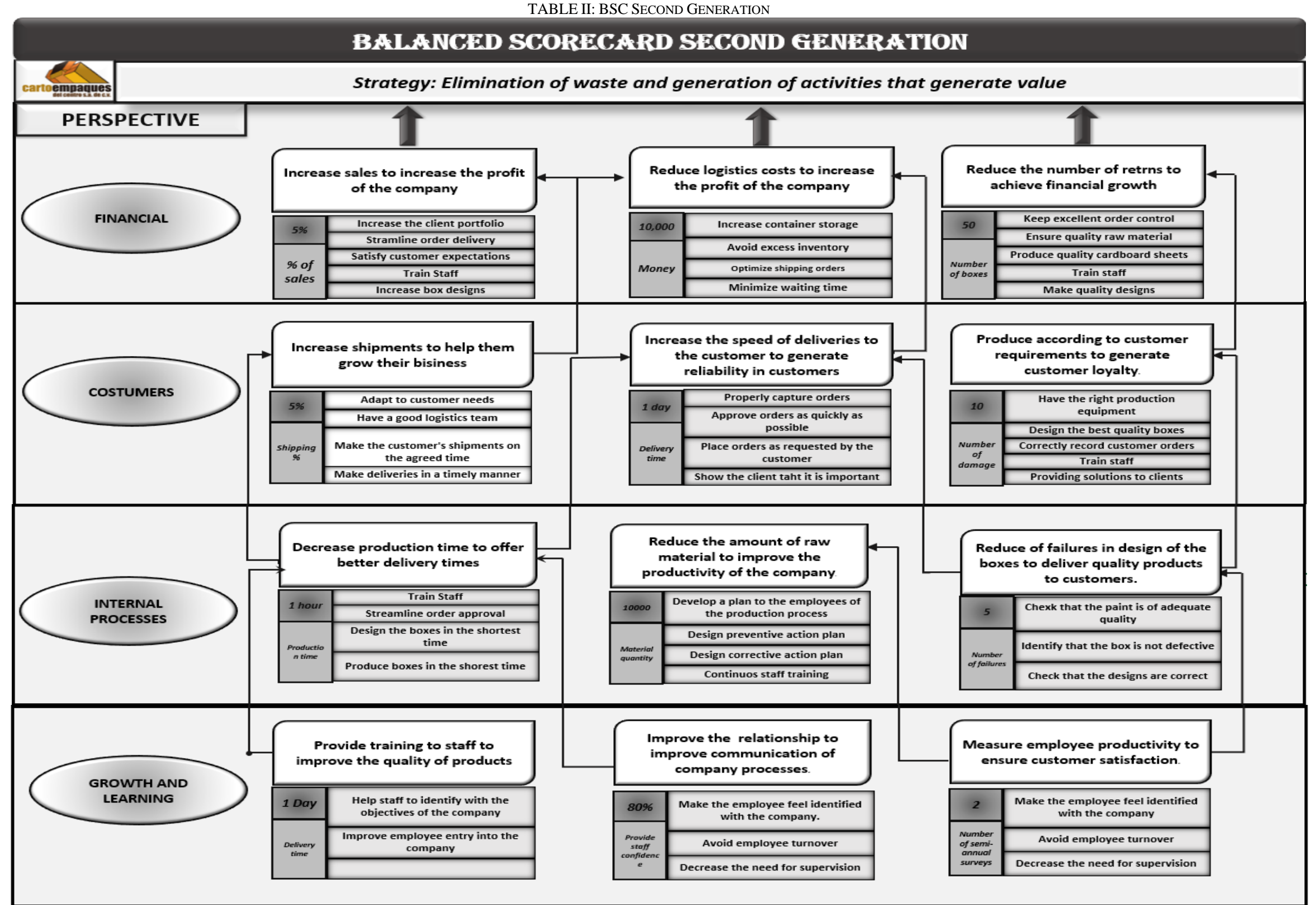




\section{CONCLUSIONS}

The Balanced Scorecard is a business performance evaluation system that has become a fundamental piece for the development of business strategy, help us to establish and focus the company's strategies for the future, is a business performance evaluation system that has become a fundamental piece for the development of business strategy. The Balanced Scorecard helps us to establish and focus the strategies of the company towards the future, to make the vision of the company a reality through four perspectives: financial, customers, Internal processes, and Knowledge and learning. In the development of the First-Generation Balanced Scorecard, we can emphasize that the most important thing for its preparation was to know the missions and vision of the company, to develop a strategy that gives it a competitive advantage. Once the strategy was developed, strategic objectives were proposed in each of the perspectives, as well as the measures and goals, without neglecting the initiatives that help us meet the established strategic objectives. For the development of the SecondGeneration Balanced Scorecard, the development of the first generation BSC was fundamental, since in this way it could visualize the most relevant strategic objectives consistent with the strategy already established, the indicator and the consequent goal were determined, as well as their initiatives.

With the development of the Balanced Scorecard First and Second generation, a tool was obtained that provides a competitive advantage to the company Cartoempaques S.A de C.V.

\section{REFERENCES}

[1] Cardozo, Edyamira; Velásquez de Naime, Yngrid y Rodríguez Monroy, Carlos (2012). La definición de PYME en América: una revisión del estado del arte. En: "6th International Conference on Industrial Engineering and Industrial Management y del XVI Congreso de Ingeniería de Organización", 18/07/2012 - 20/07/2012, Vigo, España. pp. 1345-135J. U. Duncombe, "Infrared navigation-Part I: An assessment of feasibility", IEEE Trans. Electron Devices, vol. ED11, págs. 34a39, enero de 1959.

[2] Saavedra G., María L., y Hernández C., Yolanda, y “Caracterización e importancia de las MIPYMES en Latinoamérica: Un estudio comparativo." Actualidad Contable Faces, vol. 11, no. 17, 2008, pp.122-134. https://www.redalyc.org/articulo.oa?id=25711784011.

[3] Ayala, Juan, Fernández, Rubén, y González, Ma. Leonor (2004), Capacidades tecnológicas y certificaciones de calidad: Aplicación empírica a las pymes familiares de La Rioja. Cuadernos de Gestión, 4 (1) 69-82.

[4] Salas-Arbeláez, Laura, García Solarte, Mónica, \& Murillo Vargas, Guillermo. (2017). Efecto de la cultura organizacional en el rendimiento de las PYMES de Cali. Suma de Negocios, 8(18), 8895. https://dx.doi.org/10.1016/j.sumneg.2017.11.006.

[5] . Álvarez, K y Sahui, J.A. (2009). "La interacción de los factores individuales y organizacionales como barreras del aprendizaje: problemas de actitud y tecnológicos a los que se enfrentan las pymes en México". Ensayo de Administración, (42), 89-98.

[6] Kaplan R. S. y Norton D. P. (2001): The Strategy-Focused Organization: How Balanced Scorecard Companies Thrive in the New Business Environment, Harvard Business School Press, Boston.

[7] Niven P. R. (2002): Balanced Scorecard Step-By-Step: Maximizing Performance and Maintaining Results, John Wiley \& Sons, Inc., New York.

[8] Sánchez Vázquez, José Manuel, \& Vélez Elorza, María Luisa, \& Araujo Pinzón, Pedro (2016). puntuación equilibrada para emprendedores: desde el modelo canvas al cuadro de mando integral. Revista de la Facultad de Ciencias Económicas: Investigación y Reflexión, XXIV (1), 37-47. [Fecha de Consulta 11 de diciembre de
2020]. ISSN: 0121-6805. Disponible https://www.redalyc.org/articulo.oa?id=909/90943602004.

[9] Vega Falcón, V., \& Lluglla Jácome, D. K. (2019). El Balanced Scorecard como herramienta de gestión organizacional . REVISTA CIENTÍFICA ECOCIENCIA, 6(2),

$1-24$. https://doi.org/10.21855/ecociencia.62.187.

[10] Córdova Aguirre, Luis J. (2008). Aplicación del Balanced Scorecard como metodología de gestión en las pymes y pymes peruanas. Ingeniería Industrial, (26), 85-97. [Fecha de Consulta 11 de Diciembre de 2020]. ISSN: 1025-9929. Disponible en: https://www.redalyc.org/articulo.oa?id=3374/337428492005.

[11] MICÁN, CAMILO ANDRÉS, \& JIMÉNEZ, VÍCTOR JAVIER (2012). Balanced Scorecard para la alineación de la estrategia sectorial y la función de operaciones de la industria gráfica del Valle del Cauca, Colombia. El Hombre y la Máquina, (38), 41-50. [Fecha de Consulta 11 de Diciembre de 2020]. ISSN: 0121-0777. Disponible en: https://www.redalyc.org/articulo.oa?id=478/47823946005.

[12] Alveiro Montoya Agudelo, César y Bárbaro, Juan Carlos (2011). El Balanced Scorecard como sistema de control y su aplicación como herramienta de evaluación en el ambiente bibliotecario. Revista Interamericana de Bibliotecología, 34 (1), 35-47. [Fecha de Consulta 11 de Diciembre de 2020]. ISSN: 0120-0976. Disponible en: https://www.redalyc.org/articulo.oa?id=1790/179018530003.

[13] Valenzo-Jiménez, Cazares, Martínez \& Zamudio (2018) "Perspectiva del cliente sobre una empresa textil de Guanajuato. Segundo Pilar del Balanced Scorecard" REVISTA CIENTÍFICA ECOCIENCIA, 6(2), 124.

https://www.researchgate.net/publication/239795062_A_Balanced_Sc orecard_for_Measuring_the_Impact_of_IndustryUniversity_Collaboration/stats.

[14] Lazo, Erazo \& Narváez (2019) "El Balanced Scorecard como herramienta de control interno en el sector Manufacturero". Revista Arbitrada Interdisciplinaria KOINONIA Año IV. Vol IV. $\mathrm{N}^{\circ} 1$. Edición Especial 2019 Hecho el depósito de Ley: FA2016000010 ISSN: 2542 3088. Disponible en: https://www.researchgate.net/publication/336635544_El_Balanced_S corecard_como_herramienta_de_control_interno_en_el_sector_Manu facturero.

[15] Kefe, I. (2019). The Determination of Performance Measures by Using a Balanced Scorecard Framework, Foundations of Management, 11(1), 43-56. doi: https://doi.org/10.2478/fman-2019-0004.

[16] González González, Patricia (2009). la integración del balanced scorecard (BSC) y el proceso de jerarquía analítica para efectos de jerarquizar medidas de desempeño y toma de decisión en una institución financiera. Revista Universo Contábil, 5 (2), 87-105. [Fecha de Consulta 11 de diciembre de 2020]. ISSN: 1809-3337. Disponible en: https://www.redalyc.org/articulo.oa?id=1170/117015044007.

[17] Al-Adwan, D.R. (2018). The Use of the Balanced Scorecard Performance Measurement System in Manufacturing Companies. Disponible en: https://www.semanticscholar.org/paper/The-Use-ofthe-Balanced-Scorecard-Performance-in-AlAdwan/fbfee4ef990b18cad6500ff669e62c6898b07c38. 